\title{
Problems of Institutional Provision of the State's Economic Security
}

\author{
Ekaterina A. Grigoreva
}

Kazan (Volga) Federal University (KFU), Institute of Management, Economics and Finance, Kazan, 420008, Russia ekaterina_kazan@mail.ru

\section{Doi:10.5901/mjss.2015.v6n3p499}

\begin{abstract}
In modern conditions reforming of the economy is most actively manifested in its balanced state, providing vital interests of society and dynamic socio-economic development. An important prerequisite for ensuring economic security of the state is the stability and sustainability of the national economy which presupposes property protection in all its forms, creation of reliable conditions and guarantees for business activities deterring the factors that destabilize economic development. Economic security of the state is determined by the level of productive forces development and socio-economic relations, the extent of the use of scientific and technological progress in the economy, as well as by the structure of foreign economic relations. The relevance of the study of economic security is due to the emergence of new threats that destabilize the sustainable economic development of the country. The purpose of the research is to identify the features of institutional economic security of the state, institutional contradictions of its economic security, to consider different methodological approaches to the assessment of the overall security of an economic entity, to conduct a comparative analysis of the economic security of Russia in the international scale.
\end{abstract}

Keywords: national security strategy, economic security, integral indicator of security, indicators of socio-economic development, institutional support.

\section{Introduction}

Economic security is a complex socio-economic category, which is influenced by ever-changing conditions of material production, external and internal threats of economy. Economic security is the basis of national security. National security is an essential prerogative of the state which is implemented in close cooperation with the economic agents. As an integral part of national security, economic security is the basis for formation of the military, technology, food, information and environmental safety (Tumin, V.M., A.G. Koryakov and E.P. Nikiforova, 2013). Economic security reflects the ability of the relevant political, legal and economic institutions of the state to protect interests of its key stakeholders in national economic traditions and values.

\section{Materials and Methods}

To assess the economic security in Russia, a system of indicators that reflect its place in the world economic system is used (Grigoreva, E.A., 2010). Indicators characterize the gap between indices, which, on the one hand, describe territorial space and natural resource potential, and on the other - financial capacity, gross domestic product and international trade volume and, above all, the level and quality of life. A comparison of the actual values of economic security indicators with their threshold levels that characterize various aspects of national economy security, allows to judge the dynamics of the individual components of economic security at the international level and to conduct their comparison (Ranjan Roy, Ngai Weng Chan and Ruslan Raini, 2013).

The study of literature allowed to select multiple points of view on the definition of the concept of "social and economic security". Socio-economic security depends on the level of self-sufficiency and self-financing of the region, the development of its economic potential (industrial, labor, natural, investment, innovative, scientific). Socio-economic security of the region is determined by the stability of regional economic systems' functioning (nucleating production, territorial-economic complex of the region as a whole) (Khairullov, D.S., Saipullaev, U.A., 2014). In this case, as methodological basis of the study of socio-economic security the authors have chosen a systematic approach.

National security is a case when one or more of the vital interests of our state, and / or are threatened to such an extent that it could lead to social disruption. It covers both the security threat by deliberate human acts (security) and threats from natural disasters, system or process errors, human error or natural anomalies such as extreme weather 
conditions (safety) (Mennen, M.G., van Tuyll, M.S. 2014). For the analysis of national security the author proposed risk assessment methodology (MIKR 2009).

National security is considered as a public good that is an increasing function of military spending and a negative function of the strategic environment (F-de-Cordoba, G., Torres, J.L., 2014). The author examines the economic security through dynamic stochastic models. Currently, the most common is a methodological approach that is based on the determination of relative values normalized to respective threshold levels of separate economic indicators of security (Butorin, V.K., Tkachenko, A.N., Shipilov, S.A., 2007). It is assumed that the minimum possible value of the $i$-th normalized specific index $\beta_{i, \text { min }}=0,01$ corresponds to a low level of economic security with fixed values of the other specific indicators. And, conversely, the greatest possible value of $i$-th normalized specific index $\beta_{i, \min }=0,01$ corresponds to a high level of economic security with fixed values of other specific indicators. Unit value of $i$-th normalized specific index $\beta_{i, \min }=0,01$ corresponds to threshold level of economic security of the state.

The calculation results of normalized specific indices which characterize the individual components of the economic security of the national economy of Russia, the USA, Japan, Germany, Britain, Italy, South Korea and China for 2000-2013 allowed to estimate various aspects of the economic security of these states (Ismagilov, R.F., 1999; Senchagov, V.K., Gubin, B.V., Ivanov, E.A., 2013). Methodological approach (Butorin, V.K., Tkachenko, A.N., Shipilov, S.A., 2007) to assess the level of economic security allows, on the one hand, to estimate the changes dynamics in the economic security of the state as a whole, and on the other - to compare levels of economic security of national economy in different countries.

Integral index of the overall security of an economic entity $Z_{\text {over. }}$ can be determined by the method of I. Petrenko (Petrenko, I.N., 2006), aggregating its security indices ${ }^{{ }_{i}}$ of basic security spheres:

$$
Z_{\text {общ. }}=\sum_{i=1}^{3} \alpha_{i} z_{i}
$$

where:

$i=\overline{1,3}$ - the number of security sphere of basic level including:

$i=1$ - natural and environmental spheres;

$i=2$ - production induced and industrial sphere;

$i=3$ - anthropogenic and social sphere;

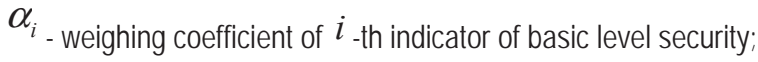

$z_{i}$ - security indicator of $i_{\text {-th }}$ sphere of basic level.

Security indicator ${ }_{i}$ of each ${ }^{i}$-th sphere of basic security level of a business entity is determined by a combination of ${ }^{m_{i}}$ security indicators ${ }^{y_{i j}}$ of the integral level (e.g. in the economy, politics, etc.):

$z_{i}=\sum_{j=1}^{m_{i}} \beta_{i j} y_{i j}$

where:

$m_{i}$ - the number of security indicators of the integral level to be included in the formation of the security indicator (aggregate) of baseline ${ }^{z_{i}}$;

$j=\overline{1, m_{i}}$ - a number of the security sphere of the integral level;

$\beta_{i j}$ - weighing coefficient of ${ }^{j}$-th index of security of the integral level;

$y_{i j}$ - security indicator of $j$-th sphere of the integral level.

This methodological approach to assessing the overall security at the micro level precludes the discussion about the limited critical value of thresholds of economic security. This is explained by the fact that an integral indicator of the overall security is formed from a set of indicators and their weighing coefficients and is a dynamic feature of the overall security of an economic entity. In this case, the threshold levels of economic security are not its extremely critical values, and act as a reference level. 


\section{Results}

The National Security Strategy of the Russian Federation (RF) until 2020 (Granberg, A.G., Danilov-Daniliyan, V.I. et al., 2002) that was approved by Presidential Decree dated May 12, 2009 № 537 identified the following indicators of the state of national security:

- the unemployment rate (the share of the economically active population);

- decile coefficient;

- growth level of consumer prices;

- $\quad$ the level of public external and internal debt as a percentage of GDP;

- the level of resources for health, culture, education and science as a percentage of GDP;

- the level of annual updating of weaponry, military and special equipment;

- $\quad$ staffing level with military, engineering and technical personnel.

The Strategy states that the list of the main indicators of the state of national security may be adjusted based on the monitoring results of the state of national security. Let us consider the actual and threshold values of macroeconomic indicators which reflect the main features of RF national interests (Table 1).

\section{Table 1}

Threshold and actual values of economic security indicators in Russia in 2013

\begin{tabular}{|c|c|c|}
\hline Indicator & Threshold value & Actual value \\
\hline GDP, bln., rub. & 29200 & 21665 \\
\hline Share of engineering in industrial output, $\%$ & 25 & 22,2 \\
\hline Grain harvest, mln, ton. & 70 & 78 \\
\hline Capital investment, \% in GDP & 25 & 15,8 \\
\hline Share of the innovative products in the total industrial production, $\%$ & 15 & $3,3^{*}$ \\
\hline Ratio of stock addition of minerals to exhausting reserves in place, $\%$ & 125 & in most types - less than100 \\
\hline Federal budget expenditures for national security, \% in GDP & 3,0 & $2,6^{*}$ \\
\hline Expenditures for citizen science, \% in GDP & 2,0 & $0,3^{*}$ \\
\hline $\begin{array}{l}\text { Percentage of population with incomes below the subsistence level of the } \\
\text { total population, } \%\end{array}$ & 7,0 & $15,8^{*}$ \\
\hline The ratio of average per capita income to the subsistence minimum, times & 3,5 & $2,8^{*}$ \\
\hline $\begin{array}{l}\text { Income ratio of } 10 \% \text { of the most wealthy and of } 10 \% \text { of the poorest } \\
\text { population (coefficient of funds), time }\end{array}$ & 8 & 14,9 \\
\hline $\begin{array}{l}\text { Unemployment rate by ILO methodology, } \% \text { of the economically active } \\
\text { population }\end{array}$ & 5 & 7,7 \\
\hline Monetization (M2) at the end of the year, \% in GDP & 50 & 25 \\
\hline The volume of gold reserves by the end of the year, billion dollars & 40 & 182,2 \\
\hline External and internal public debt, \% in GDP by the end of the year & 60 & 16,1 \\
\hline $\begin{array}{l}\text { The ratio of the cost of servicing the external public debt to total } \\
\text { expenditure of the federal budget, } \%\end{array}$ & 20 & $4,6^{*}$ \\
\hline Inflation level, \% & 125 & 110,9 \\
\hline Federal budget deficit, \% in GDP & 3,0 & budget surplus \\
\hline The share of imported food in the total volume of food resources, $\%$ & 25 & 40 \\
\hline
\end{tabular}

Note: * estimates of the Ministry of Economic Development and Trade Ministry, the Finance Ministry to the draft of the federal budget for 2013.

Table 1 shows that the values of individual indicators (inflation, budget deficit, public debt) were below the threshold, and the volume of foreign exchange reserves is several times higher than threshold level.

The Russian Security Council approved the official list of socio-economic indicators of economic security (Prokopov, B.I., 2008) that reflect critical points of the Russian economy development (Table 2). 


\section{Table 2}

Socio-economic indicators of economic security of the Russian Federation

\begin{tabular}{|l|c|}
\hline Indicators & Threshold values \\
\hline The amount of investments,\% of GDP & 25 \\
\hline Expenditure on research,\% of GDP & 2 \\
\hline The proportion of people whose income is below the subsistence minimum,\% & 7 \\
\hline Life expectancy, years & 70 \\
\hline Decile ratio, times & 8 \\
\hline The crime rate (per 100 thousand people) & 5 \\
\hline Inflation level, \% & 20 \\
\hline External public debt, \% of GDP & 25 \\
\hline Budget deficit,\% of GDP & 5 \\
\hline Money supply, M2,\% of GDP & 50 \\
\hline The share of imports in domestic consumption, total: & 30 \\
including food\% & 25 \\
\hline Unemployment rate (ILO methodology),\% & 7 \\
\hline
\end{tabular}

The indicators presented in Table 2 characterize the limit values beyond which normal course of economic and social development is hindered and it leads to the formation of destructive tendencies in the national economy of the country (Kadochnikova, E.I., Khisamova, E.D., 2014).

The economic literature has repeatedly raised the issue of poor sectoral structure of the Russian economy (Glukhov, E.V. and V.V. Glukhov, 2013; Feofilova, T.Y., 2012). Fuel and raw materials base of Russian production and export threatens the stable functioning and development of the economy. Predominance of processing industries in the economic structure is due to their high capabilities in terms of sustainability and profitability of production. In the engineering and chemical industries new high-tech products come to the fore: manufacturing computers and laser technology, automation, equipment for nuclear power, microbiological drugs and materials. In Russia, the share of processing industries and sectors which define scientific and technological progress, not only lags behind the developed countries, but also tends to decrease (Socio-economic indicators of the Russian Federation. Federal State Statistics Service. [Electronic resource]- URL: http://www.gks.ru/).

In 2013, in the sectoral structure of the Russian industry the share of electric power accounted for $9.3 \%$, fuel industry - 18.4\%; metallurgy - 18\%; forest, woodwork and timber industry and paper - $4.7 \%$; chemical petrochemical 9.6\%; mechanical engineering and metal processing - 18.1\%; light and food industry - 18.1\% (Socio-economic indicators of the Russian Federation. Federal State Statistics Service. [Electronic resource]- URL: http://www.gks.ru/). The structural backwardness of Russian economy entails its instability and limits its development opportunities. Proceeds from the sale of mineral raw materials and energy products are completely determined by the market and do not depend on the efforts of manufacturers (Vorobiev, A.E., Balykhin, G.A., Komashchenko, V.I., 2007; Ankudinov, A.B. and O.V. Lebedev, 2013). This means that changing economic situation in the world, discovery of new large oil fields outside Russia, a technological breakthrough in the use of new construction materials and fuel sources, development of resource saving technologies may reduce the need for mineral resources and lead to a significant fall in their prices. Thus, the problem of structural modernization of Russian economy is paramount in ensuring competitiveness and economic security (Grigoreva, E., Fesina, E., 2014).

\section{Conclusion}

National Security Concept of the Russian Federation notes that the threats in the Russian economy are of integrated nature. They are due to the weakening of the scientific-technical and technological potential of the country, economic disintegration, social differentiation of the society, devaluation of spiritual values, the criminalization of social relations, growing terrorism and organized crime (Safiullin, M.R., L.A. Elshin, A.I. Shakirova, P.O. Ermolaeva and M. I. Prygunova, 2013; Malaev, V.V., Nizamutdinov, I.K., 2014). However, the listed threats are not disclosed in full in the document, which does not allow to define their specific boundaries, their reality and severity and to develop a unified national approach to neutralize threats. National Security Concept of the Russian Federation does not reflect the major threats to the economic development of the regions where the criminalization of the economy is significant. In particular, it does not consider economic and tax crimes, shadow economy, gray labor market. Since the adoption of this document economic, social 
and political situation in Russian regions, as well as in the world has changed significantly (Gubaidullina, T.N., 2015). This means that the criteria for economic security remain constant because they consist in maintaining the state of protection of the vital interests of the national economy and the population, but the factors and conditions of economic security are constantly changing, reflecting the processes of transformation of the Russian economy, leading to the emergence of new threats and dangers in the development of social and economic system.

\section{References}

Ankudinov, A.B. and O.V. Lebedev (2013). Institutional Environment and Value of Companies. World Applied Sciences Journal, 23 (11), 1560-1569.

Butorin, V.K., Tkachenko, A.N., Shipilov, S.A. (2007). Fundamentals of economic security. 3 volumes. V 1. System concept of economic security. Kemerovo.

F-de-Cordoba, G., Torres, J.L. (2014). National security, military spending and the business cycle. Defence and Peace Economics.

Feofilova, T.Y. (2012). Problems of the theory of economic security. Problems of the modern economy. Eurasian international scientific and analytical journal, 4, 103-106.

Glukhov, E.V. and V.V. Glukhov (2013). Meaning and Essence of Scientific Concept "Business Finance" in Market-Oriented Economy. World Applied Sciences Journal, 25 (10), 1405-1408.

Granberg, A.G., Danilov-Daniliyan, V.I. et al. (2002). Strategy and sustainable development issues of Russia in the XXI century. Moscow.

Grigoreva, E., Fesina, E. (2014). Economic Security as a Condition of Institutional Support of Economy Modernization. World Applied Sciences Journal, 31 (5), 940-948.

Grigoreva, E.A. (2010). Economic security in the context of the global financial crisis. Bulletin of the Kazan State Agrarian University, 4 (18), 20-23.

Gubaidullina, T.N. (2015). Systemic Approach in the Study of Problems of Territories's Sustainable Ecological and Economic Development. Mediterranean Journal of Social Sciences, 6 (1), 232-236.

Ismagilov, R.F. (1999). The economic security of Russia: Theory and Practice: Monograph. St. Petersburg.

Kadochnikova, E.I., Khisamova, E.D., (2014). The use of regional accounts system when analyzing economic development of the region. Mediterranean Journal of Social Sciences, 5 (24), 383-387.

Khairullov, D.S., Saipullaev, U.A., (2014). Management of Social and Economic Security of the region. Mediterranean Journal of Social Sciences, 5 (12), 177-182.

Malaev, V.V., Nizamutdinov, I.K. (2014). Inequality and economic growth in the Russian economy. Mediterranean Journal of Social Sciences, 5 (24), 346-350.

Mennen, M.G., van Tuyll, M.C. (2014). Dealing with future risks in the Netherlands: the national security strategy and the national risk assessment. Journal of Risk Research.

Petrenko, I.N. (2006). Security Essentials of functioning businesses. Moscow.

Prokopov, B.I. (2008). The nature and content of economic security. Problems of the modern economy. Eurasian international scientific journal, 4, 144-148.

Ranjan Roy, Ngai Weng Chan and Ruslan Raini (2013). Development of Indicators for Sustainable Rice Farming in Bangladesh: A Case Study with Participative Multi-Stakeholder Involvement. World Applied Sciences Journal, 22 (5), 672-682.

Safiullin, M.R., L.A. Elshin, A.I. Shakirova, P.O. Ermolaeva and M. I. Prygunova (2013). Influence of Territorial Ecological Load Factors on Social and Economic Well-Being of Population: Methodology Development and Econometric Model Construction. World Applied Sciences Journal, 25 (7), 1057-1061.

Senchagov, V.K., Gubin, B.V., Ivanov, E.A. (2013). Long-term strategy of economic security of the Russian Federation for the period up to 2016. Russia in the globalizing world. Moscow.

Socio-economic indicators of the Russian Federation. Federal State Statistics Service. [Electronic resource]- URL: http://www.gks.ru/

Tumin, V.M., A.G. Koryakov and E.P. Nikiforova (2013). The Main Factors of Socio-Ecological-Economic Stability and Development of Industrial Enterprises. World Applied Sciences Journal, 25 (6), 945-949.

Vorobiev, A.E., Balykhin, G.A., Komashchenko, V.I. (2007). National mineral security of Russia: current problems and perspectives. Moscow. 